\title{
AC 2009-2243: A STUDENT BIDDING PROCESS APPLIED TO INDUSTRIALLY SPONSORED SENIOR CAPSTONE DESIGN PROJECTS
}

\section{Robert Todd, Brigham Young University}

Robert H. Todd is a professor of Mechanical Engineering at Brigham Young University and the founding director of BYU's Capstone program. During the 2008-2009 academic year BYU completed its 515 th industrially sponsored project with cross-functional teams of Sr. engineering and technology students through the Capstone course. Dr. Todd received his PhD from Stanford University in Mechanical Engineering Design, taught engineering courses and served in department and college administration at BYU-Idaho (then Ricks College) before spending 10 years in industry in senior level engineering and management positions with both the General Motors Corporation and the Michelin Tire Corporation in both the U.S. and Europe. His research and teaching interests include manufacturing process machine design and development and the development and improvement of engineering education in a global setting. Since coming to BYU in 1989, he has been the Sr. author of two manufacturing processes books, one a best seller used thought out the world, and numerous technical articles. He has served as a department chair and undergraduate coordinator, a member of the Engineering Accreditation Commission (EAC) of ABET (the Accreditation Board for Engineering and Technology). He is a recipient of BYU's Karl G. Maser Excellence in Teaching award, the Mechanical Engineering Department's Outstanding Teacher and Rudy Awards, the Department's Outstanding Achievement Award, and BYU's Blue Key College of Engineering and Technology Outstanding Faculty award. He is a Fellow of the American Society for Engineering Education. He and his wife Janell have been blessed with 8 children and 17 grandchildren. He restores antique automobiles as a hobby.

\section{Christopher Mattson, Brigham Young University}

Christopher A. Mattson received his BS and MS in mechanical engineering from Brigham Young University and his $\mathrm{PhD}$ in mechanical engineering from Rensselaer Polytechnic Institute. Prior to joining BYU, Prof. Mattson was the Global Director of Engineering Design and Research at ATL Technology and a member of the company's executive committee. He established and managed ATL's Silicon Valley office (1999-2000), and ATL's twenty-five person Engineering Design Center in mainland China (2004-2006). He has designed or led the design of various products, which have been used by over 15 million people around the world. He has over 20 articles published in journals and conference proceedings, has been an invited lecturer at two universities in China, and holds two patents. He is a member of ASME, AIAA, and Sigma Xi. Prof. Mattson has served as a member of the AIAA Multidisciplinary Design Optimization Technical Committee since 2003.

\section{Gregg Warnick, Brigham Young University}

External Relations and Intern Coordinator for the Mechanical Engineering department in the Ira A. Fulton College of Engineering and Technology at BYU. He works directly with industry to recruit projects for Capstone and is working to increase international project opportunities for students. Interests include global technology issues, project management, ethics, and manufacturing processes. Gregg has a Master of Technology Management degree and a BS in Manufacturing Engineering Technology, from Brigham Young University. He is completing a $\mathrm{PhD}$ in Educational Leadership and Higher Education from the University of Nebraska with an emphasis on globalization and leadership. He is a Certified Manufacturing Technologist, Society of Manufacturing Engineers, and is also certified in Planning and Managing Projects, BD University; Lean Manufacturing, BD University; High Impact Facilitation, Lore International Institute, Durango, Colorado; and Project Management, Saddle Island Institute.

\section{Ryan Dymock, Brigham Young University}

Ryan Dymock is currently a senior studying Mechanical Engineering at Brigham Young 
University. He hopes to steer his career in the direction of robotics and automation, and so far has had 3 internships with different manufacturing companies. His extracurricular studies at BYU have included wind tunnel testing air foils for VTOL aircraft, building a Fatigue Tester and CAD simulation for components of the BYU formula car, being the TA for the Advanced Robotics class, as well as mentoring his 6th grade robotics team to 1st place in their district wide competition. He currently lives in Provo, Utah with his wife, Leah, and his 18 month old daughter Samantha. Samantha has been a good sport in dealing with both parents concurrently seeking degrees from BYU, both graduating in April of 2009. 


\title{
A Student Bidding Process Applied to Industrially-Sponsored Senior Capstone Design Projects
}

\begin{abstract}
Since ABET 2000, numerous engineering programs have initiated industrially-sponsored Senior Capstone courses designed to better prepare students for the practice of engineering. Brigham Young University initiated an industrially sponsored Capstone program in 1990. Since 1990, BYU student teams have completed more than 500 of these projects.

Project teams in Capstone courses have been formed using a variety of methods. At BYU, student test results from the Herrmann Brain Dominance, FIRO B, and other tests have been used to form teams. The intent has been to create diversity of thinking among team members to provide a better learning experience for the students and better project results than would be obtained if diversity in team formation was not sought. After team formation, each team has been assigned an industriallysponsored project.
\end{abstract}

Beginning in 2008, teams were formed in a way similar to previous semesters and then invited to take part in a 'bidding' process for the 27 industrially sponsored projects. This bidding process was initiated as an experiment in an effort to foster increased ownership for project success among team members and as an initial exercise to foster familiarity between team members and to start working together immediately.

This paper presents preliminary results of this new approach, including survey results from Capstone students who were involved in the bidding process and those from alumni currently pursuing graduate degrees at Brigham Young University who in previous years had their Capstone projects assigned without being involved in bidding. Comparisons are drawn between the two groups. Advantages and disadvantages are noted and recommendations are given.

\section{Introduction}

Capstone courses have become a widespread culminating experience in undergraduate engineering programs across the United States. The achievement of capstone course outcomes is often based on the premise that students most effectively learn design by active engagement in and application of previous learning to 'real open-ended', design problems. These courses have become largely universal as a result of engineering programs seeking to better meet the needs of industry and accreditation requirements specified with the advent of ABET $2000^{1,2}$.

The Chronicle of Higher Education recently cited much of the motivation for developing capstone courses in engineering programs. "The National Science Foundation, the National Academy of Engineering, and others have been warning for at least two decades that American engineering education is too theoretical and not hands-on enough," and a "new Carnegie report...reinforces those warnings." The report indicates "that a widespread emphasis on theory over practice...discourages many potential students while leaving graduates with too little exposure to real-world problems and ethical dilemmas." While "millions of dollars" have been offered "through a coalition of universities to try to break up old styles of teaching," many schools "still 
couldn't overcome the 'cultural issue of change' among faculty members." There have been some successes, however. Georgia Tech's biomedical engineering program uses a "problem-based approach" that "helps attract and teach many types of engineering students, especially women, who have been traditionally reluctant to consider engineering." ${ }^{3}$ In general, capstone courses are considered of high educational value by both students and faculty alike ${ }^{4}$.

Comprehensive surveys of engineering programs in the U.S. involving capstone courses in 1994 and 2005 reveal that these courses often use industrial sponsored projects. ${ }^{3,5}$ In fact, the use of industrially sponsored projects for capstone courses has increased from 59\% of respondents in 1994 to $71 \%$ in 2005. In addition, the programs that responded to these surveys reported a decrease of projects being performed by individual teams from $32 \%$ in 1994 to $18 \%$ in 2005 . The use of interdisciplinary project teams has increased from $21 \%$ in 1994 to $35 \%$ in $2005 .{ }^{4}$

Howe and Wilbarger also report that the great majority of programs (81\%), however, still use teams made up of students from a single discipline. ${ }^{4}$ Most capstone courses occur over one or two semesters, but an increasing number of programs have design courses that span more than a single year. Most courses also involve class work and a project being offered either simultaneously or in parallel. Additionally, these surveys show that the number of subjects and professional skills, such as teamwork and leadership, being taught in capstone courses are increasing.

Considering team formation and project assignments for teams, the 2005 data indicates that $71 \%$ of programs use one project per student team, an increase compared to 62\% in 1994. Most programs (49\% in 1994 and $60 \%$ in 2005) also use team sizes ranging from four to six students. ${ }^{4}$

An earlier survey reported that industry was eager to have engineering education prepare students to work in teams. ${ }^{1}$ Today, it is common knowledge that much of the project design work in industry is conducted in teams and that capstone programs, for the most part, have adopted the use of teams.

The method of formation of teams has been a topic of much consideration. Various methods of team formation are currently used in capstone courses with the common goal of maximizing team efficiency and student learning. While some programs allow students to self-select their teammates, others take a more active approach. Often effort is made to balance the skills, interests, and personalities of each project team. ${ }^{1}$ These factors are often discovered through the use of questionnaires and personality tests.

Scott and Pollock report that personality testing is the most effective method for selecting students when forming teams ${ }^{6}$. She posits that having a team made up of students with similar skills and experience does not equate to consistent success. In cases where performance lacked, it "was believed to be a result of poor team development, which occurred due to the incompatibility of team members' personalities." Her program utilizes what she calls a 'semi self-selected' strategy, which allows students to self-select teams, but adjustments are made by a faculty member from the department of Industrial Psychology. This faculty member takes into consideration surveys filled out by students and makes adjustments where necessary. Many different programs currently use similar personality based indicators to guide them in team formation. $5,7,8,9$ 
Although much has been researched and evaluated in regards to team formation, the act of specific project assignment has not been given near as much attention. This may be for a few reasons. Even though engineering programs are emphasizing more cross-disciplinary collaboration, as mentioned previously, the percentage is still low. It may be inferred that each team should have the technical ability to perform any of the sponsored projects. With the limited time that instructors have for preparing a senior design course, it makes sense that many choose to allocate more resources to team formation, since so much research has been done on its correlation to effectiveness.

Some programs also combine the process of team formation and project selection into the same step. For example, Lamancusa et al. describe a process where students are given a packet of one page summaries of each project. The students have an opportunity to meet the industry sponsors during a luncheon and then 'bid' on their top choices. Prior to this, the students will have taken a profile test to help determine their preferred team role. After the bids are received, faculty members from all of the participating classes meet to collaborate on team formation and project selection. "Every attempt is made to satisfy the students' first or second choice, while also trying to avoid the embarrassment of telling a sponsor that 'no one chose your project. "'7

Freiheit and Wood from the University of Calgary have implemented an algorithm that takes into consideration a bidding process similar to Lamancusa's. Students are given project descriptions and then apply to work on up to three projects. With their bid, they also submit a brief resume of their talents, interests, and background. The algorithm "attempts to place students into projects such that the overall project assignment solution provides the highest 'satisfaction'." ${ }^{10}$ These authors claim that use of the algorithm requires just one quarter the preparation time necessary compared to other manual methods. Other programs have implemented the use of automated selection tools as. Unlike previously discussed methods, the University of Calgary does not use any kind of personality metric, due to its time-consuming nature and resistance to automated methods. ${ }^{11}$

Emanuel and Worthington wrote of a Bradley University program that sought to create teams of equal strengths. Each student was familiarized with the available projects and then submitted their top two choices to the faculty. The faculty then listed each student under their first and second choices. Changes were then made until there were three members on each team, in addition to meeting predetermined criteria of 'balance'. Balance was defined by four categories: interest in the project, academic strength, work experience, and personality. Personality was determined using the Meyers-Briggs Type Indicators. ${ }^{12}$

Their experiment yielded results that did not match the anticipated outcome. They had hoped that by considering personality differences, teams would be able to internally resolve potential conflicts and solve problems synergistically. However, this was not the case as each group experienced significant personality conflicts throughout the semester. They attributed this to the students trying to conform to the roles prescribed by their personality test results rather than being themselves. In later semesters, they choose to not use the personality indicators in forming teams. Instead, they utilized the results to address problems that occurred partway through the semester. They concluded that the Meyers-Briggs indicators are better used as a team-building tool instead of a team-forming tool. ${ }^{12}$ 
The University of Cape Town allows students to not only choose their project, but to search for it. At the beginning of their yearlong design project, they are given two weeks to "find a sponsor in industry with a business problem that best fits the generic project brief." 6

One reason for allowing students to have a say in their design project is the common belief that choice promotes an increase in motivation. Todd comments that allowing students to have a choice in their learning promotes more enjoyment and that if they "have some choice in the project they work on, they may have greater motivation than if they are assigned arbitrarily." ${ }^{8}$

Although this belief is widely accepted, Katz and Assor assert that it is only true in the right context. The mere offering of choice does not stimulate motivation, and in some cases, can reduce motivation. They propose that, "in order for choice to be motivating, it has to be based on a careful match between the various options and the students' needs, interests, goals, abilities, and cultural background."13 Motivation increases when students find the project interesting and valuable, when they feel like they are capable of completing the project, and when they are more focused on outcomes than grades. ${ }^{14}$

\section{BYU's Previous, Non-Bidding Approach to Team Project Assignments}

This section of the paper briefly introduces a no-bid approach to assigning industry-sponsored projects to capstone teams as used in previous BYU Capstone years. The no-bid approach consists of the five main activities described below.

Activity 1: Pre-semester survey of students' skills. Students are asked to rate their proficiency in such areas as machining, analytical modeling, CAD, and creativity. The results are cataloged in a database used in Activity 3 (below).

Activity 2: Instructors' identification of skills needed for each project's success. The instructors consider the objective of each project, and identify the engineering and project management skills needed to successfully complete it. The projects are evaluated one-by-one, with frequent reference to the sponsor-provided project proposal or through direct contact with the sponsor.

Activity 3: Execution of a numerical algorithm that forms teams based on skill diversity, educational (major) diversity, and cognitive approach. The algorithm seeks to form teams that are comparable to other teams in terms of overall skill, thereby giving each team a relatively equal opportunity for success.

Activity 4: Preliminary assignment of projects to teams and coaches. Preliminary assignments are based on skills available within the team and skills believed necessary for project success. Coaches are selected based on their background and interest.

Activity 5: Refinement and final assignment of coaches, teams, and project assignments. This activity is based on the instructors' familiarity with individual students, projects, coaches and any special needs that may exist with the students, sponsors, or coaches. 
The successes and benefits connected to this no-bid approach are not discussed here. One notable drawback, however, - the impetus for developing a bid-based approach - is that students' interests and career goals are not generally considered in the no-bid approach discussed above. For many students, the capstone project is the first major design project they will participate in. To improve the experience for the students, a bid-based approach that considers their interests has been developed and tested. The approach is based on the assumption that students will be more likely to take more ownership for their learning and the success of the project when they have had an opportunity to have some choice in their project, based on their interests and goals.

\section{BYU's Bid-Based Approach to Assigning Senior Capstone Projects}

This section describes an approach for assigning industry-sponsored projects to capstone teams based on team bids for projects. We choose to use the word "bidding", to emphasize the need for students to take inventory of their skills and use those skills as currency in the project assignment process. The bidding approach comprises four main phases, which are described in more detail below. The four phases are: (i) pre-bidding preparation by the instructors, (ii) information gathering by the team, (iii) bidding for projects by the team, and (iv) evaluation of proposals and assignment of projects by the instructors. The approach described here was used by the BYU Capstone instructors in the 2008-2009 academic year. Each of the four phases of the bid-based approach is discussed below in general terms with some details regarding the approach implementation, where needed. Student survey results and discussion from the 2008-2009 BYU bid-based approach are presented in the Results section of this paper.

\section{Phase 1: Pre-bidding preparation by the instructors.}

The objective of this phase is to prepare project information that will assist teams in quickly selecting projects to bid on. Any information deemed important to the selection of projects should be accessible to the teams. At least the following should be made available:

a. A one-paragraph description of each available project,

b. The original project proposals from the sponsoring companies,

c. Details about the companies, such as liaison engineer, location, and web address,

d. The name and contact information for the faculty coach assigned to the project. The project information listed above is particularly important because some teams may wish to base their bidding decision solely on the nature of the project, while others may base their decision on the sponsoring company, company proximity to the campus, the coach assigned to the project, or on a combination thereof.

Generally speaking, the project information listed above is already available to the Capstone instructors. Therefore, this phase in the approach is simply the process of compiling the information and making it accessible to the student teams.

For the 2008-2009 academic year, the BYU Capstone instructors summarized each project proposal, as received from the sponsoring company, in a one-paragraph description that was made available to the students via an online database. Each paragraph was crafted with the intent of attracting students to bid for the project. Also included in the one-paragraph description was the name of the company and their web address. If the students were to request additional information 
about the project, the original project proposal was also readily available for distribution to the inquiring team. The instructors also assigned coaches to projects during this phase of the process. The coaches were assigned based on the coach's expertise, background, and, to some extent, interest. Coaches were also instructed to review the company's proposal, contact the company, if necessary, and to be prepared to answer student's questions about the project and encourage teams with desirable skill sets to bid for the project.

\section{Phase 2: Information gathering by the team}

From the student's perspective, this phase in the bid-based approach represents the beginning of the bidding process. Within one week of the initiation of this phase, the teams are assigned the project that they will work on. The purpose of this phase is for the teams to gather any information that will help them select projects the team can successfully complete. This information includes factors that are both external (project information prepared by the instructors in Phase 1) and internal to the team (team members' skills, interests, and background).

For the 2008-2009 academic year, the BYU Capstone instructors provided student teams with four resources to gather information that would help them form a bidding strategy. This included (i) an easy way to search through a summarized project list including one-paragraph project descriptions online, and throughout the bidding process, (ii) a project open-house, where assigned coaches to the various projects could be met in person and provide more information on their specific project, (iii) team-time during class hours to discover the team member's skills and interests, and (iv) a global posting of the bidding competition. That is, a real time listing of what the team's plans were for bidding on projects.

Online examination of short project descriptions allowed the teams and individual team members to assess potential projects at their own pace as a team and individually. Attending the project open-house with the faculty coaches helped the students get to know the coaches and also how each coach viewed their particular project.

During the project open house, each coach was positioned within a large room and was given a sign with their project name written in large type. This activity could be considered as a 'Project Fair', much like a 'job fair'. The students walked around during this one-hour session, meeting with only those coaches they wished to spend time with. Coaches used their own approaches to attract students and to describe the skills that he or she felt would be needed for the project. Team time during class hours was left to the discretion of the teams to determine how to best identify the skills and interests of each team member.

Finally, each team had an opportunity to examine the competition that would ensue for project bidding. This was done by asking each team to mark on a centrally-posted board which projects they planned to bid on. Team identifiers were used to note which teams planned to bid on which projects. This allowed teams to consider how stiff the competition might be in the bidding process. Teams were also asked to erase their identifier if they had decided not to bid for a particular project after all. It is in the best interest of the team to indicate their bidding intentions. 


\section{Phase 3: Bidding for projects by the team}

Once the team has examined the potential projects, sponsoring companies, coaches assigned to the project, number of other teams bidding for projects, and the skills and interests of their own team members, the team is in a good position to select and bid for projects. Each team bids for no more than three projects; indicating their first, second, and third preference. Teams may also decide to bid on zero projects, thereby deferring to the judgment of the instructors in assigning the team a project.

To bid on a project, the teams submit a one-page (maximum) proposal for each of their three preferences. In the proposal, the team describes why the team is best suited to carry-out and succeed in meeting the needs of the industrial sponsor for the prospective project. They are encouraged to list specific skills that are needed to solve the specific design problem at hand and how the team's skills match those that are needed. Teams are also encouraged to be clear and professional in their writing and to include a statement regarding how each proposed project would complement their engineering education.

For the 2008-2009 BYU Capstone program, every team chose to bid for projects; Twenty-five of twenty-seven teams chose to bid for three projects, while two teams bid for only one or two projects. The same ratio (25/27) of projects received at least one bid.

\section{Phase 4: Evaluation of proposals and project assignments by instructors}

After the bidding window closes, each proposal is evaluated and teams are assigned to the projects. Proposal evaluations are first considered project by project. The project with the most first preference bids is the project evaluated first. For this project, all proposals are read and scored by multiple judges. If the top-rated proposal is the team's first preference, then the team is awarded the project and all of the other proposals for that team are removed from the pool of proposals. To preserve the meaning of first, second, and third preferences, a team's higher preference is always considered over a lower preference. For example, if the top-rated proposal is not the team's first preference, then the projects for which the team has expressed higher preferences are evaluated concurrently with the project under consideration; and should the same team have the top-rated proposal for a higher-preference project, then the team is awarded the higher preference project. The team's higher preference is always considered over a lower preference, even when it means fewer teams will receive their first, second, or third preference or when a project has no other teams bidding on it.

In the 2008-2009 academic year, three judges - including the instructors - evaluated each proposal based on professionalism, skills needed, and impact to their education. Coaches and teams were notified of project assignment results based upon the bidding process and coaches were asked to have a kick-off meeting with their team within a few days of the team assignment.

A four phase bid-based approach for assigning projects to capstone teams has been described in this section. The approach presented here provides one method for student teams to select projects to bid on and provides a clear basis for proposal writing and evaluation. Project assignments are based on the quality of team proposals and the team's preference for projects. 
The intent was to have three notable results come from the bid-based approach. They are, (i) team members quickly get to know one another in terms of skills, personalities, and interests, (ii) teams have the opportunity to be involved in choosing their own direction, thereby instilling more project ownership on the part of the teams, and (iii) teams have the opportunity to consider what skills are needed to be successful for a given project and to align their own skills with the available projects.

\section{Results}

This section presents results of the BYU experience in implementing the bidding process described in the previous section. Surveys were administered to current students near the beginning of the fall semester, shortly after the bidding process was conducted and teams were assigned their projects based on the process. In addition, surveys with similar questions were administered to these same students near the end of the first semester or at the start of the second semester of the two-semester Capstone course. This survey was also given to a sample of students who were alumni of the previous Capstone course where a non-bidding process was used to assign student teams to projects.

The BYU Capstone course had the following enrollment for the 2008-2009 academic year:

\begin{tabular}{l|l|l} 
Discipline & $\begin{array}{l}\text { Fall } 2008 \\
\text { \# of Students }\end{array}$ & $\begin{array}{l}\text { Winter 2009 } \\
\text { \# of Students }\end{array}$ \\
\hline Chemical Engineering & 1 & 0 \\
\hline Computer Engineering & 1 & 1 \\
\hline Construction Management & 1 & 1 \\
\hline Economics & 1 & 0 \\
\hline Electrical Engineering & 3 & 3 \\
\hline Manufacturing Engineering Technology & 3 & 30 \\
\hline Mechanical Engineering & 126 & 126 \\
\hline Total & $\mathbf{1 3 6}$ & $\mathbf{1 6 1}$
\end{tabular}

As described previously, a brief survey was conducted approximately one week after student project teams were formed, assessing outcomes (key learnings) from the project bidding process. One hundred thirty-two out of one hundred thirty-six (97\% response rate) students responded with the following four items representing the most commonly cited key learnings:

- Helped me get to know my team members quickly

- Helped me learn about the strengths/skills of each team member

- Helped me learn about other capstone projects and company sponsors

- Helped me learn more about proposal development and communication 
Capstone students also provided additional qualitative feedback concerning the project bidding process. A few representative comments are included below:

"Bidding on projects is representative of what happens in industry and helps increase commitment to selected projects. In addition, it is not always possible to work on the projects you want in industry."

"The worst case scenario with the project bidding process (to be assigned a project) is no different than what happened in previous years."

"Students care more for projects when they compete for them."

"Bidding helps me feel more excited and committed to my project."

"It would be less frustrating to be just assigned to a project."

"A team that does not get assigned to a project they bid on may be less motivated to perform well on the project."

"I would be a lot less satisfied with an assigned project."

"The bidding process helps match the best qualified teams with the appropriate projects."

"Bidding is better than the old system of being assigned to projects."

"Bidding provides each team an opportunity to have a say in their selected project."

"I liked the bidding process since it made it feel like real life. It was the first bidding process I have ever been part of."

"It is disappointing knowing that you did not get any projects that you bid on."

"We did not get any of the projects our team bid for, but I am now happy with my project."

"The bidding process helps teams realize the importance of developing a thorough proposal that communicates the qualifications and interests of team members."

Students also provided a few recommendations for improving the project bidding process within BYU's Capstone course:

Allow students to form [their] own teams based upon individual interest and then use project bidding approach.

Make sure that coaches know more about the projects to provide students more detail in the project bidding process.

Have more projects available than teams to increase potential project opportunities.

In addition to having teams identify projects they are interested in, have them rank their choices.

Provide teams more time with the assigned faculty coach before bids are submitted. This can include a longer question/answer period or presentations from each coach.

"The bidding process helps teams realize the importance of developing a thorough proposal that communicates the qualifications and interests of team members." 
In addition, quantitative data was gathered to determine if students were satisfied with the project bidding process results and whether they would recommend the same approach in future years. Eighty-eight percent $(88 \%)$ of students indicated that they were satisfied with the results and eighty-nine percent (89\%) recommend the same project bidding approach in future years (See Figure 1). This data indicates that the project bidding approach should likely be used in future years.

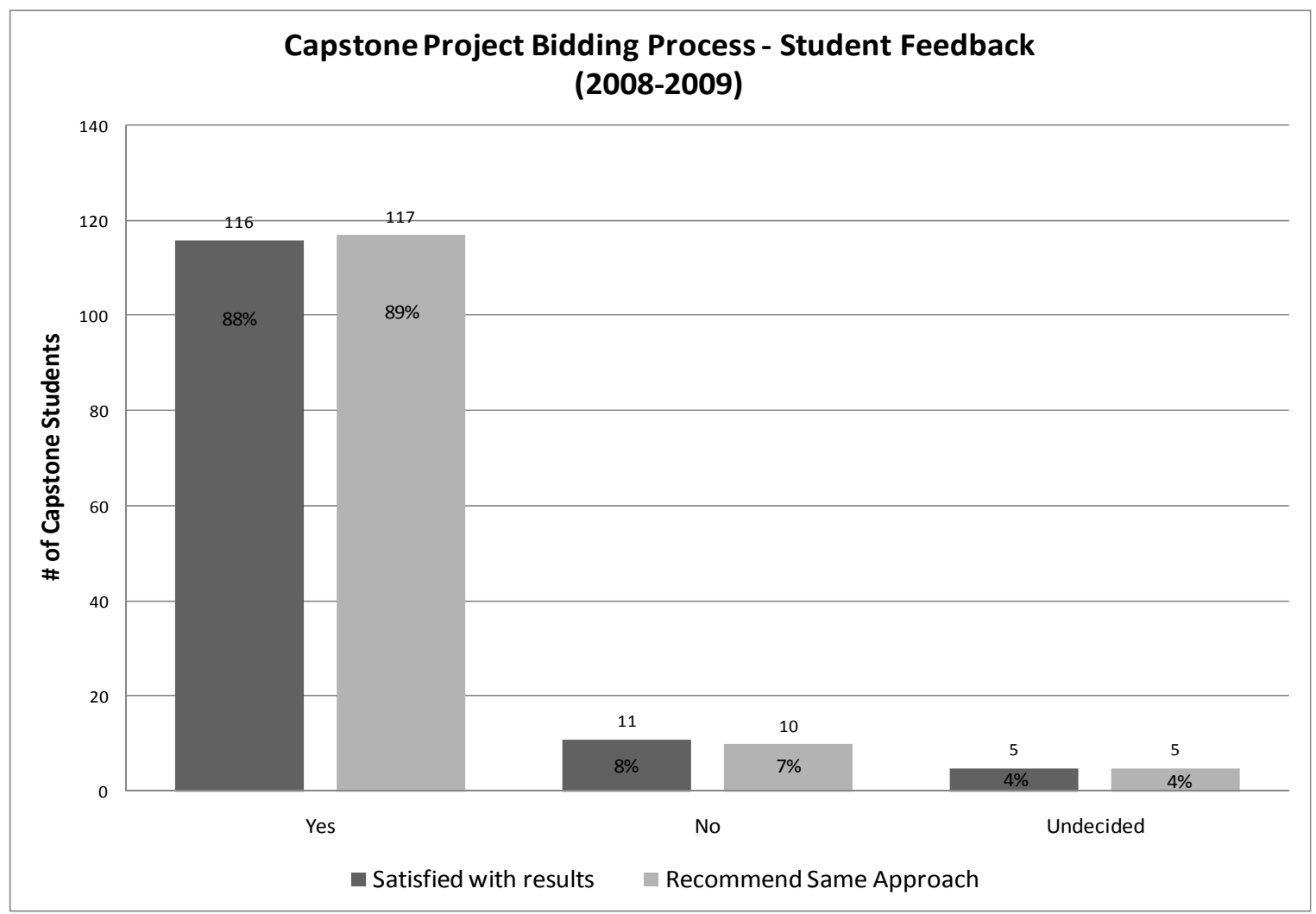

Figure 1. BYU Capstone Student Feedback for Project Bidding Process

To further assess the project bidding process, an additional follow-up survey (See Appendix A) was administered to Capstone students at the end of the first semester (December 2008). One hundred eleven out of one hundred thirty-six Capstone students completed the survey ( $82 \%$ response rate). Students were asked to respond to questions using a five-point Likert scale $(1=$ strongly disagree to $5=$ strongly agree) for the following questions:

\section{1) Before the Capstone project assignment:}

a) I worried about what my project would be

b) I had relevant subject matter knowledge \& experience for my project.

\section{2) The Capstone project bidding process:}

a) Helped me get to know my team members quickly

b) Helped me learn about the strengths/skills of each team member

c) Helped me learn about other Capstone projects and company sponsors

d) Helped me learn more about proposal development and communication 


\section{3) Project assignment statement}

a) I was satisfied with the project assignment (project bidding process results)

b) My team, as a whole, was satisfied with the project assignment

c) My assigned project enabled me to learn more about subjects relating to my career goals

d) I prefer the opportunity we had to bid on projects versus having them directly assigned

e) My project work and ownership in the project outcomes has increased as a result of the project bidding process

f) My motivation on the project has increased as a result of the project bidding process

g) My learning has been enhanced as a result of the project bidding process

h) As the semester progressed, I became more satisfied with my project assignment.

i) My Capstone experience would have been better if I had been assigned a different project

j) The specific project assignment does not affect the experience a student has in the Capstone course.

k) I would recommend that Capstone use the same project bidding approach in future years

A similar survey (See Appendix B) was administered to former Capstone students that are currently pursuing graduate degrees at Brigham Young University. The survey was sent to 96 graduate students with 21 responses ( $22 \%$ response rate). All questions were the same as the survey given to current Capstone students with the exception of the following four questions:

\section{3) Project assignment statement}

d) I would have preferred the opportunity to bid on projects versus having them directly assigned

e) My project work and ownership in the project outcomes would have been better if my team would have had the opportunity to bid on projects

f) My motivation on the project would have been higher if we could have bid on projects

g) My learning would have increased if we could have bid on projects

Results from these surveys are summarized in Figures 2 and 3 . Figure 2 illustrates how students (current and past) felt before the Capstone project assignment and also how they felt about the Capstone project bidding process or first week design competition (e.g. a design competition, 'payload delivery' project to help team members to get to know one another and start working together). This activity was used during the first week of the fall semester in prior years. 


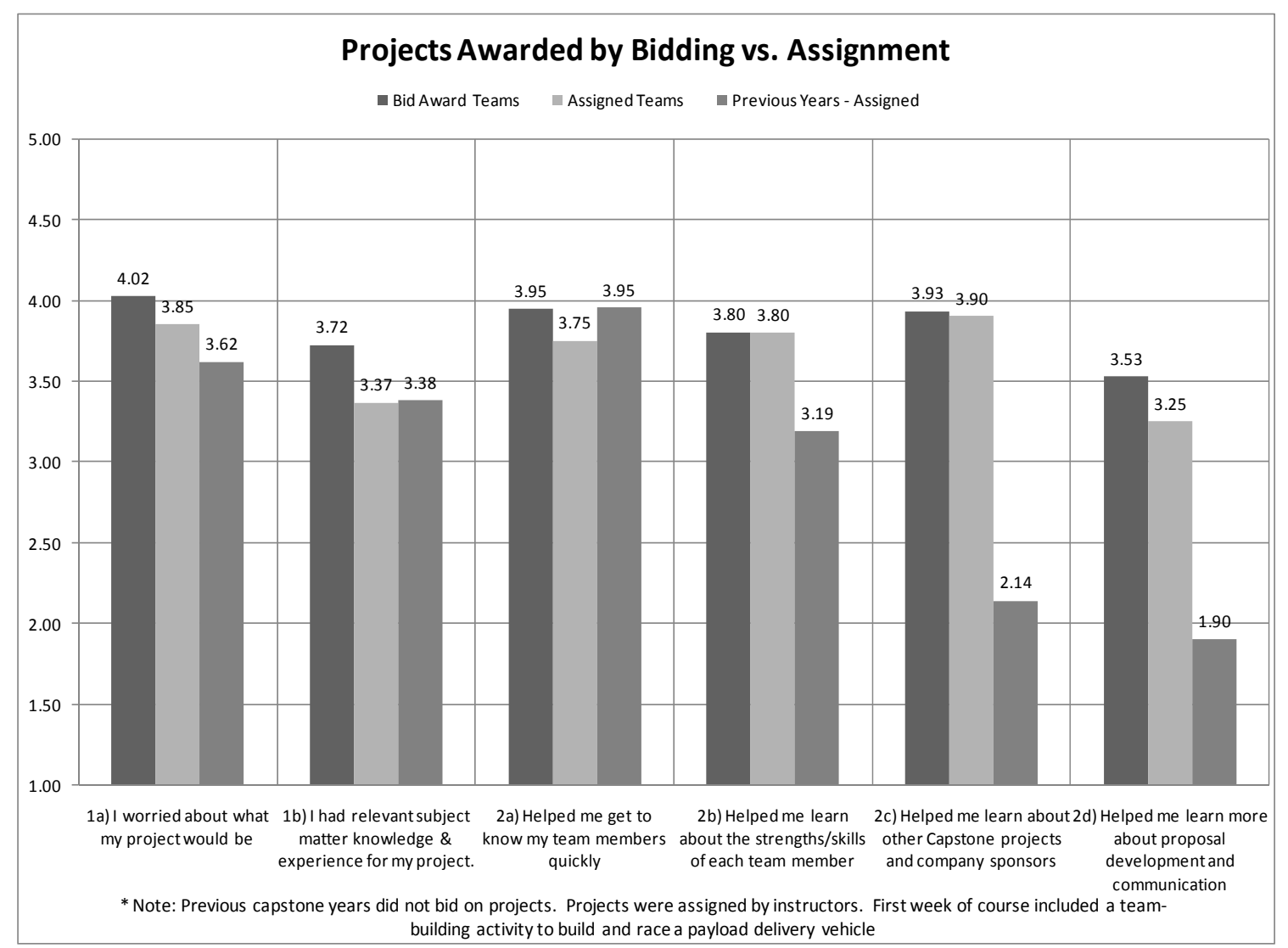

Figure 2. BYU Capstone Student Feedback: Items 1,2 - End of Fall Semester

These results indicate that students worry about what project they will be assigned and that either the project bidding process or design competition is effective in helping individuals within teams get to know each other including strengths and weaknesses. However, it is clear that the project bidding process is much more effective in helping students learn more about other Capstone projects and company sponsors. A Likert score near 4 (3.93 and 3.90) from current Capstone students indicates agreement that the project bidding process is effective in helping teams get to know other projects and company sponsors. Former Capstone students, in general, indicated that the design competition did not help with this as indicated with a Likert score slightly above 2 . Results for proposal development and communication also indicate that the project bidding process is much more effective in providing this experience for students.

Figure 3 illustrates general agreement that students (both current and former) prefer the opportunity to bid on projects. Former Capstone students were generally in favor of the opportunity to bid on projects with $86 \%$ of respondents either neutral or in agreement with this process. Current Capstone students who were awarded projects based upon their submitted bids are very supportive of the project bidding process for future years with a score of 4.14 indicating very strong agreement. Even students who were assigned projects this year were only in slight disagreement of using the bidding process in future years with a response of 2.85. It is interesting to note that students who were assigned to projects for the current Capstone year (2008-2009) did not feel that their commitment or motivation increased (questions $3 \mathrm{e}$ and $3 \mathrm{f}$ ) as a result of the project bidding process. This could be indicative of disappointment in not receiving a project of original interest. However, these same students had the most positive response to their project 
satisfaction increasing as the semester progressed with an average Likert score of 3.95, indicating agreement.

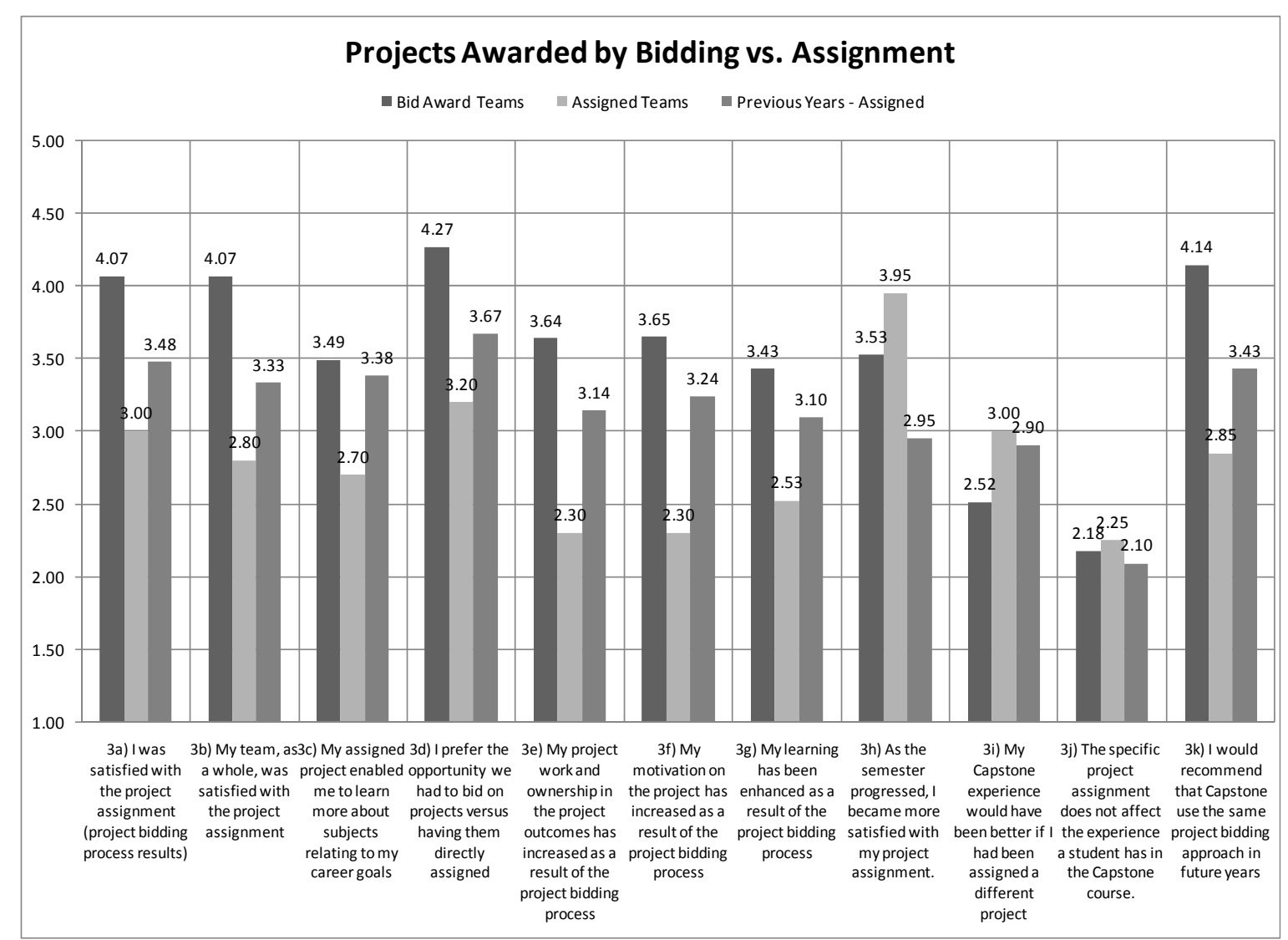

Figure 3. BYU Capstone Student Feedback: Item 3- After End of Fall Semester

\section{Conclusions and Recommendations}

We have briefly described various methods and factors from the literature concerning how Capstone teams are formed and of particular interest to this paper, how projects are assigned to teams. The literature is much more complete concerning how teams are formed than how projects are assigned to teams.

A more detailed description of how BYU has assigned projects to teams in the past has been presented. A description of how a new bidding process has been implemented at BYU was also presented. Survey results of current and past students responding to this new bidding process have also been presented.

The survey results indicate that, in general, students favor the new bidding process over the previous assignment method. Students also worry about what project they will be assigned to. The bidding process is much more effective in helping students learn more about other Capstone projects and company sponsors than the previous assignment method. 
It is also of interest that the students who did not get their choice of projects in the bidding process and were assigned to projects did not feel that their commitment or motivation increased (questions $3 \mathrm{e}$ and $3 \mathrm{f}$ of the survey) as a result of the project bidding process. However, these same students had the most positive response to their project satisfaction increasing as the semester progressed with an average Likert score of 3.95, indicating agreement.

Based on our experience and findings thus far, we would recommend using a bidding process to assign student teams to projects. The bidding process should be tailored to accomplish the learning outcomes that exist for a given Capstone course. In addition, it is clear that additional potential exists for refining the use of a bidding process to assist students in gaining the important Capstone course learning outcomes associated with industrially sponsored projects.

\section{References}

1 Todd, R.C., C. Sorensen, and S. Magleby. 1993. Designing a senior capstone course to satisfy industrial customers. Journal of Engineering Education 82 (2): 92-100.

2 ABET. 2009. http://www.abet.org/forms.shtml\#For_Engineering_Programs_Only (accessed January 27, 2009).

3 Chronicle of Higher Education. 2009. Why engineering schools are slow to change. http://chronicle.com/daily/2009/01/10003n.htm (accessed January 22, 2009).

4 Howe, S. and J. Wilbarger. 2006. 2005 National survey of engineering capstone design courses. Proceedings of the 2006 ASEE Annual Conference and Exposition. Chicago, IL: American Society of Engineering Education.

5 Todd, R.H., S.P. Magleby, C.D. Sorensen, B.R. Swan and D.K. Anthony. 1995. A survey of capstone engineering courses in North America. ASEE Journal of Engineering Education 84 (2): 165-174.

6 Scott, E.C. and M. Pollock. 2006. Effectiveness of self-selected teams: A systems development project experience. The Journal of Informing Science and Information Technology (IISIT) 3: 601- 618.

7 Lamancausa, J., A. Soyster, and R. George. 1997. Industry based projects in academia-What works and what doesn't. Proceedings of the 1997 ASEE Annual Conference and Exposition. Milwaukee, WI: American Society of Engineering Education.

8 Todd, R.H. and S.P. Magleby. 2005. Elements of a successful capstone course considering the needs of stakeholders. European Journal of Engineering Education. 30 (2): 203-214.

9 Jack, H. 2007. A methodology for assigning project teams. Proceedings of the 2007 ASEE Annual Conference and Exposition. Allendale, MI: American Society of Engineering Education.

10 Freiheit, T. and J. Wood. 2007. An algorithm for project assignment in capstone design. Proceedings of the 2007 ASEE Annual Conference and Exposition. Allendale, MI: American Society of Engineering Education.

11 Cavanaugh, R., M. Ellis, R. Layton, and M. Ardis. 2004. Automating the process of assigning students to cooperative learning teams. Proceedings of the 2004 ASEE Annual Conference and Exposition. Salt Lake City, UT: American Society of Engineering Education.

12 Emanuel, J.T. and K. Worthington. 1989. Team-oriented capstone design course management: A new approach to team formulation and evaluation. Proceedings of ASEE Frontiers in Education Conference. Piscataway, NJ: American Society of Engineering Education.

13 Katz, I. and Assor, A. 2007. When choice motivates and when it does not. Educational Psychology Review. 19 (4): 429-442.

14 Blumenfeld, P.C., E. Soloway, R. Marx, J.S. Krajcik, M. Guzdial, and A. Palincsar. 1991. Motivating projectbased learning: Sustaining the doing, supporting the learning. Educational Psychologist. 26 (3-4): 369-398. 


\section{Appendix A}

\section{Capstone Project Bidding Process Survey}

For the 2008-2009 Capstone course, each team was given background information on 27 industry-sponsored projects and then was given an opportunity to bid (develop a proposal) on their top three choices. Project assignments were made based on the quality of a written proposal and how well the team's collective qualifications and interests matched the project's objectives.

Please indicate your agreement with the following statements, using the following scale:

$$
\begin{array}{ll}
1=\text { Strongly Disagree (SD) } & 4=\text { Agree (A) } \\
2=\text { Disagree (D) } & 5=\text { Strongly Agree (SA) }
\end{array}
$$

Team \#

\begin{tabular}{|c|c|c|c|c|c|c|}
\hline 1) & Before the Capstone project assignment: & SD & $\mathrm{D}$ & $N$ & A & SA \\
\hline a) & I worried about what my project would be & $\mathrm{O}$ & $\mathrm{O}$ & $\mathrm{O}$ & $\mathrm{O}$ & $\mathrm{O}$ \\
\hline b) & I had relevant subject matter knowledge \& experience for my project. & 0 & $\mathrm{O}$ & 0 & $\mathrm{O}$ & $\mathrm{O}$ \\
\hline
\end{tabular}

(Enter team \# only)

\begin{tabular}{|c|c|c|c|c|c|c|}
\hline 2) & The Capstone project bidding process: & SD & $\mathrm{D}$ & $\mathbf{N}$ & A & SA \\
\hline a) & Helped me get to know my team members quickly & 0 & $\mathrm{O}$ & O & 0 & 0 \\
\hline b) & Helped me learn about the strengths/skills of each team member & 0 & 0 & 0 & 0 & 0 \\
\hline c) & Helped me learn about other Capstone projects and company sponsors & 0 & 0 & 0 & 0 & 0 \\
\hline d) & Helped me learn more about proposal development and communication & 0 & 0 & 0 & 0 & 0 \\
\hline
\end{tabular}

\begin{tabular}{|c|c|c|c|c|c|c|}
\hline 3) & Project assignment statement & SD & $\mathrm{D}$ & $\mathbf{N}$ & A & SA \\
\hline a) & I was satisfied with the project assignment (project bidding process results) & $\mathrm{O}$ & $\mathrm{O}$ & $\mathrm{O}$ & $\mathrm{O}$ & $\mathrm{O}$ \\
\hline b) & My team, as a whole, was satisfied with the project assignment & 0 & $\mathrm{O}$ & $\mathrm{O}$ & $\mathrm{O}$ & $\mathrm{O}$ \\
\hline c) & My assigned project enabled me to learn more about subjects relating to my career goals & $\mathrm{O}$ & 0 & $\mathrm{O}$ & 0 & 0 \\
\hline d) & I prefer the opportunity we had to bid on projects versus having them directly assigned & 0 & 0 & $\mathrm{O}$ & $\mathrm{O}$ & 0 \\
\hline e) & $\begin{array}{l}\text { My project work and ownership in the project outcomes has increased as a result of the project bidding } \\
\text { process }\end{array}$ & $\mathrm{O}$ & $\mathrm{O}$ & $\mathrm{O}$ & $\mathrm{O}$ & $\mathrm{O}$ \\
\hline f) & My motivation on the project has increased as a result of the project bidding process & 0 & 0 & 0 & 0 & 0 \\
\hline g) & My learning has been enhanced as a result of the project bidding process & 0 & O & 0 & 0 & 0 \\
\hline h) & As the semester progressed, I became more satisfied with my project assignment. & 0 & 0 & 0 & 0 & 0 \\
\hline i) & My Capstone experience would have been better if I had been assigned a different project & 0 & O & 0 & 0 & 0 \\
\hline j) & The specific project assignment does not affect the experience a student has in the Capstone course. & 0 & 0 & 0 & $\mathrm{O}$ & 0 \\
\hline k) & I would recommend that Capstone use the same project bidding approach in future years & 0 & 0 & 0 & 0 & 0 \\
\hline
\end{tabular}




\section{Appendix B}

\section{CAPSTONE PROJECT BIDdING PROCESS SURVEY}

For the 2008-2009 Capstone course, each team was given background information on 27 industry-sponsored projects and then was given an opportunity to bid (develop a proposal) on their top three choices. Project assignments were made based on the quality of a written proposal and how well the team's collective qualifications and interests matched the project's objectives.

As a former capstone student, we are interested in your feedback concerning your capstone project assignment and the option of having students develop proposals (bid) for project assignments. Please complete the requested project information and indicate your agreement with the following statements, using the following scale:

$$
\begin{array}{ll}
1=\text { Strongly Disagree (SD) } & 4=\text { Agree (A) } \\
2=\text { Disagree (D) } & 5=\text { Strongly Agree (SA) }
\end{array}
$$

\begin{tabular}{|c|c|c|c|c|c|c|}
\hline 1) & Before my Capstone project assignment: & $\mathrm{SD}$ & $\mathrm{D}$ & $\mathrm{N}$ & A & SA \\
\hline a) & I worried about what my project would be & O & 0 & $\mathrm{O}$ & $\mathrm{O}$ & $\mathrm{O}$ \\
\hline b) & I had relevant subject matter knowledge \& experience for my project. & $\mathrm{O}$ & 0 & $\mathrm{O}$ & $\mathrm{O}$ & 0 \\
\hline 2) & The first week design competition (e.g. payload delivery project): & SD & $\mathrm{D}$ & $\mathbf{N}$ & A & SA \\
\hline a) & Helped me get to know my team members quickly & $\mathrm{O}$ & $\mathrm{O}$ & 0 & $\mathrm{O}$ & $\mathrm{O}$ \\
\hline b) & Helped me learn about the strengths/skills of each team member & 0 & 0 & 0 & 0 & 0 \\
\hline c) & Helped me learn about other Capstone projects and other company sponsors & $\mathrm{O}$ & $\mathrm{O}$ & 0 & $\mathrm{O}$ & $\mathrm{O}$ \\
\hline d) & Helped me leam more about proposal development and communication & $\mathrm{O}$ & 0 & $\mathrm{O}$ & $\mathrm{O}$ & $\mathrm{O}$ \\
\hline 3) & Project assignment statement & SD & $\mathrm{D}$ & $\mathbf{N}$ & A & SA \\
\hline a) & I was satisfied with my assigned caps tone project & 0 & 0 & 0 & 0 & 0 \\
\hline b) & My team, as a whole, was satisfied with the project assignment & $\mathrm{O}$ & $\mathrm{O}$ & $\mathrm{O}$ & $\mathrm{O}$ & $\mathrm{O}$ \\
\hline c) & My assigned project enabled me to learn more about subjects relating to my career goals & $\mathrm{O}$ & $\mathrm{O}$ & $\mathrm{O}$ & $\mathrm{O}$ & $\mathrm{O}$ \\
\hline d) & I would have preferred the opportunity to bid on projects versus having them directly assigned & $\mathrm{O}$ & $\mathrm{O}$ & O & $\mathrm{O}$ & $\mathrm{O}$ \\
\hline e) & $\begin{array}{l}\text { My project work and ownership in the project outcomes would have been better if my team would have } \\
\text { had the opportunity to bid on projects }\end{array}$ & $\mathrm{O}$ & $\mathrm{O}$ & 0 & $\mathrm{O}$ & $\mathrm{O}$ \\
\hline f) & My motivation on the project would have been higher if we could have bid on projects & 0 & 0 & 0 & 0 & 0 \\
\hline g) & My learning would have increased if we could have bid on projects & $\mathrm{O}$ & 0 & 0 & $\mathrm{O}$ & $\mathrm{O}$ \\
\hline h) & As the semester progressed, I became more satisfied with my project assignment. & O & $\mathrm{O}$ & $\mathrm{O}$ & $\mathrm{O}$ & $\mathrm{O}$ \\
\hline i) & My Capstone experience would have been better if I had been assigned a different project & O & 0 & 0 & 0 & 0 \\
\hline i) & The specific project assignment does not affect the experience a student has in the Capstone course. & 0 & 0 & $\mathrm{O}$ & $\mathrm{O}$ & $\mathrm{O}$ \\
\hline k) & I would recommend that Capstone use a project bidding approach in future years & O & 0 & 0 & 0 & 0 \\
\hline
\end{tabular}

Capstone Course Year $\quad$ to
Project Team \#
Sponsor

Additional Comments 